\title{
Serum zinc levels in 368 patients with oral mucosal diseases: A preliminary study
}

\author{
Zhe-Xuan Bao ${ }^{1,2}$, Xiao-Wen Yang ${ }^{3}$, Jing Shi ${ }^{2}$, Li-Xin Liu ${ }^{4}$ \\ ${ }^{1}$ First clinical medical school of Shanxi Medical University, Taiyuan, Shanxi, China \\ ${ }^{2}$ Department of Oral Medicine, Shanxi Provincial People's Hospital, Taiyuan, Shanxi, China \\ ${ }^{3}$ Department of Hospital Infection Control, Shanxi Provincial People's Hospital, Taiyuan, Shanxi, China \\ ${ }^{4}$ Department of Gastroenterology and Hepatology, The First Clinical Hospital of Shanxi Medical University, Taiyuan, Shanxi, \\ China
}

Correspondence:

Department of Gastroenterology and Hepatology

The First Clinical Hospital of Shanxi Medical University

Mailbox 427, 85 Jiefang South Road, Taiyuan, Shanxi Province

China. 030001

lixinliu6@hotmail.com

Bao ZX, Yang XW, Shi J, Liu LX. Serum zinc levels in 368 patients with oral mucosal diseases: A preliminary study. Med Oral Patol Oral Cir Bucal. 2016 May 1;21 (3):e335-40.

http://www.medicinaoral.com/medoralfree01/v21i3/medoralv21i3p335.pdf

Received: 06/10/2015

Accepted: 27/01/2016

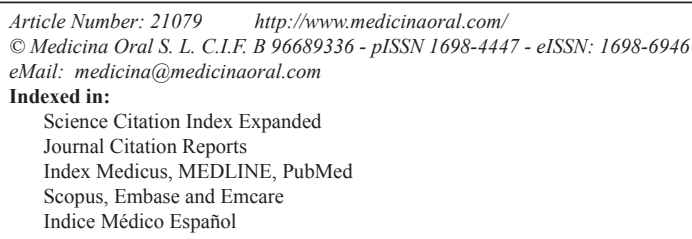

\begin{abstract}
Background: The aim of this study was to assess the serum zinc levels in patients with common oral mucosal diseases by comparing these to healthy controls.

Material and Methods: A total of 368 patients, which consisted of 156 recurrent aphthous stomatitis (RAS) patients, 57 oral lichen planus (OLP) patients, 55 burning mouth syndrome (BMS) patients, 54 atrophic glossitis (AG) patients, 46 xerostomia patients, and 115 sex-and age-matched healthy control subjects were enrolled in this study. Serum zinc levels were measured in all participants. Statistical analysis was performed using a one-way ANOVA, t-test, and Chi-square test.

Results: The mean serum zinc level in the healthy control group was significantly higher than the levels of all other groups $(p<0.001)$. No individual in the healthy control group had a serum zinc level less than the minimum normal value. However, up to $24.7 \%$ (13/54) of patients with AG presented with zinc deficiency, while $21.2 \%$ (33/156) of patients with RAS, 16.4\% (9/55) of patients with BMS, 15.2\% (7/46) of patients with xerostomia, and $14.0 \%(8 / 57)$ of patients with OLP were zinc deficient. Altogether, the zinc deficiency rate was $19.02 \%(70 / 368)$ in the oral mucosal diseases (OMD) group (all patients with OMD). The difference between the OMD and healthy control group was significant $(p<0.001)$. Gender differences in serum zinc levels were also present, although not statistically significant.

Conclusions: Zinc deficiency may be involved in the pathogenesis of common oral mucosal diseases. Zinc supplementation may be a useful treatment for oral mucosal diseases, but this requires further investigation; the optimal serum level of zinc, for the prevention and treatment of oral mucosal diseases, remains to be determined.
\end{abstract}

Key words: Oral mucosal diseases, Zinc deficiency, pathogenesis. 


\section{Introduction}

Oral mucosal diseases (OMD) are common disorders affecting all segments of the general population that represent a series of abnormal alterations in oral mucosal surfaces, which include the labial and buccal mucosae, the alveolar mucosa, all parts of tongue, the floor of the mouth, and the gingival, palatal, and oropharyngeal mucosae $(1,2)$. Although the majority of OMDs are benign, some of them are difficult to manage and usually interfere with important oral functions, systemic health, and quality of life of the patients.

Recurrent aphthous stomatitis (RAS), oral lichen planus (OLP), burning mouth syndrome (BMS), atrophic glossitis (AG), and xerostomia are some of the most prevalent oral mucosal diseases and they typically require multiple visits to specialist outpatient services. However, the etiology and pathogenesis of these disorders is still poorly understood and highly debated (2-5).

Zinc, one of the most important trace elements within the human body, plays a variety of critical roles in cell growth and reproduction, normal immune functions, collagen synthesis, and wound healing $(6,7)$. And zinc deficiency is related to multiple physiological abnormalities. Therefore, it is plausible that zinc deficiency might be directly involved in the pathogenesis of some oral mucous diseases (Fig. 1). At the present, the available literature concerning serum zinc levels in patients with oral mucosal diseases is severely limited. Moreover, findings from several of these studies are inconsistent $(4,8-14)$ (Table 1), which demonstrates that further research is needed.

The aim of this study was to assess the serum zinc levels of patients with some of the most common oral mucosal diseases as compared to healthy controls to determine if zinc deficiency may play a role in the etiology and pathogenesis of oral mucosal disease.

\section{Material and Methods}

A total of 368 patients, consisting of 156 RAS patients, 57 OLP patients, 55 BMS patients, 54 AG patients and 46 xerostomia patients were enrolled in this study. Sex- and age-matched healthy control subjects were also examined (115 total controls). All participants were evaluated from January 2013 to May 2015 at the Department of Oral Medicine, Shanxi Provincial People's Hospital, China. An OMD diagnosis was established according to accepted criterions $(1,4,13-20)$ (Table 2). Other less common diseases, such as oral leukoplakia (OLK), discoid lupus erythematosus (DLE), oral acute infection, allergic reactions, and seasonal disorders, such as cheilitis, were not included in this study. None of the control subjects had any oral mucosal lesions or related systemic diseases.

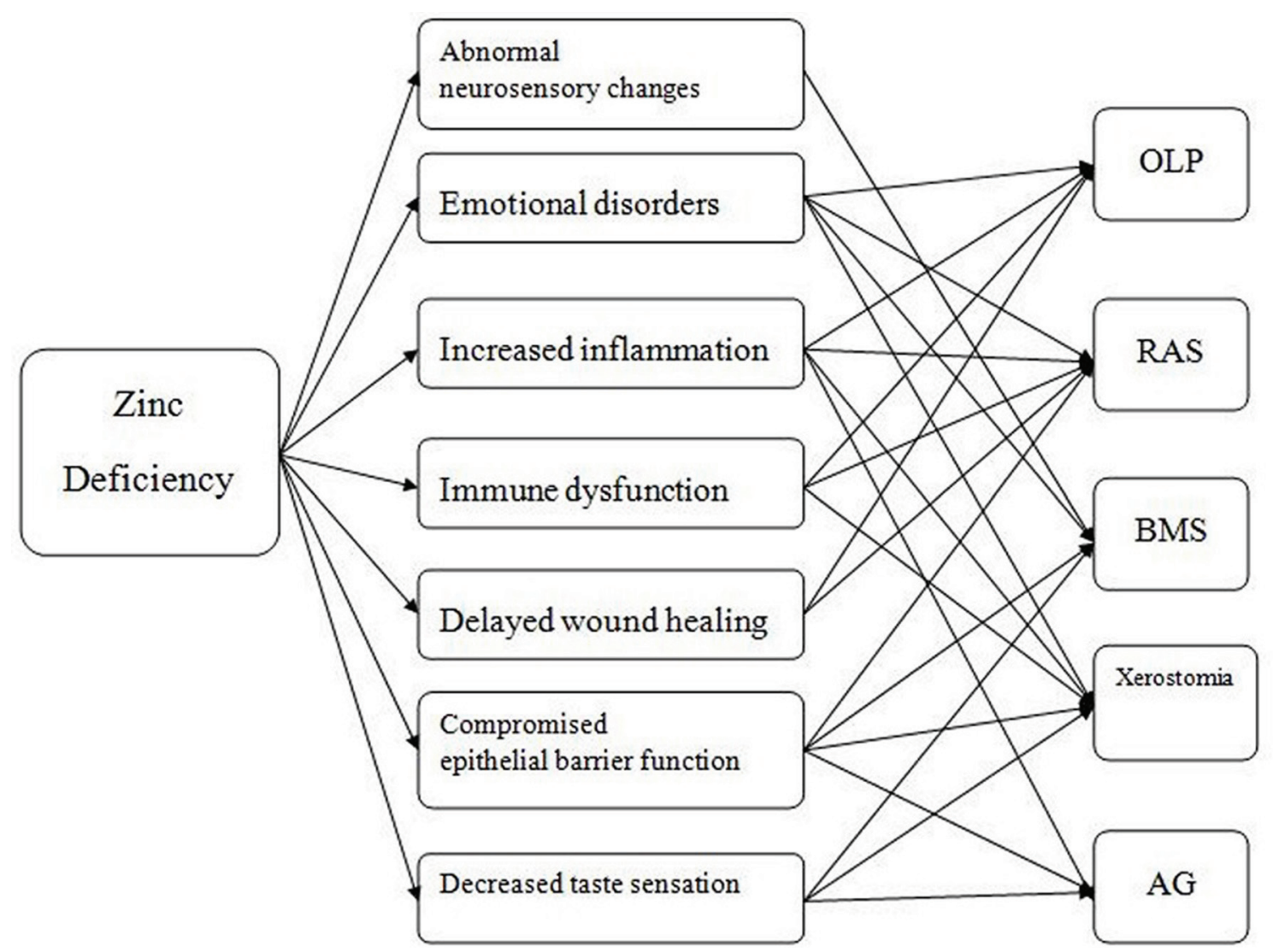

Fig. 1. Zinc deficiency may be involved in the pathogenesis of common oral mucosal diseases through a variety of mechanisms. OLP: oral lichen planus. RAS: Recurrent aphthous stomatitis. BMS: burning mouth síndrome. AG: atrophic glositis. 
Table 1. Existing reports of zinc deficiency in oral mucosal diseases in the past three decades.

\begin{tabular}{|c|c|c|c|c|c|}
\hline Country/city & Year(ref) & $\begin{array}{c}\text { Oral } \\
\text { mucosal } \\
\text { diseases }\end{array}$ & $\begin{array}{l}\text { NO.of subjects } \\
\text { (gender composition) }\end{array}$ & $\begin{array}{l}\text { The } \\
\text { proportion } \\
\text { of Zinc } \\
\text { deficiency }\end{array}$ & Conclusion \\
\hline England/London & 1982(8) & RAS & $\begin{array}{l}25 \text { patients ( } 11 \text { males } \\
\text { and } 14 \text { females) }\end{array}$ & 0 & $\begin{array}{l}\text { Systemic zinc supplementa- } \\
\text { tion is not recommended }\end{array}$ \\
\hline Turkey/Erzurun & 2003(9) & RAS & $\begin{array}{l}40 \text { patients ( } 14 \text { males, } \\
26 \text { females) }\end{array}$ & $42.5 \%$ & $\begin{array}{l}\text { Zinc deficiency is associated } \\
\text { with RAS. } \\
\text { Systemic zinc supplementa- } \\
\text { tion is recommended }\end{array}$ \\
\hline Turkey/Hatay & 2014(10) & RAS & $\begin{array}{l}25 \text { patients ( } 12 \text { males } \\
\text { and } 13 \text { females) } \\
25 \text { healthy controls ( } 13 \\
\text { males and } 12 \text { females) }\end{array}$ & $\begin{array}{l}28 \% \text { of RAS } \\
4 \% \text { of controls }\end{array}$ & $\begin{array}{l}\text { Zinc deficiency is a potential } \\
\text { aetiological factor for RAS }\end{array}$ \\
\hline England/London & 1991(11) & BMS & $\begin{array}{l}30 \text { patients ( } 8 \text { males, } 22 \\
\text { females) } \\
30 \text { healthy controls ( } 8 \\
\text { males, } 22 \text { females) }\end{array}$ & $\begin{array}{l}30 \% \text { of BMS } \\
10 \% \text { of controls }\end{array}$ & $\begin{array}{l}\text { Zinc deficiency may be } \\
\text { associated with BMS }\end{array}$ \\
\hline Korea/ Seoul & 2010(4) & BMS & $\begin{array}{l}276 \text { patients (not men- } \\
\text { tioned in detail) }\end{array}$ & $26.8 \%$ & $\begin{array}{l}\text { Zinc deficiency might play } \\
\text { a role in BMS and zinc } \\
\text { replacement therapy is } \\
\text { effective }\end{array}$ \\
\hline Norway/Oslo & $2000(12)$ & $\mathrm{AG}$ & $\begin{array}{l}311 \text { subjects in the } \\
\text { hospital group } \\
\text { (140 males, } 171 \text { fema- } \\
\text { les) } \\
106 \text { subjects in the } \\
\text { home group } \\
\text { ( } 54 \text { males, } 52 \text { females) }\end{array}$ & not mentioned & $\begin{array}{l}\text { The AG is not related to the } \\
\text { serum zinc level }\end{array}$ \\
\hline Japan / Tokyo & 2002(13) & Xerostomia & $\begin{array}{l}93 \text { patients ( } 27 \text { males, } \\
66 \text { females) } \\
60 \text { healthy controls } \\
\text { ( } 29 \text { males, } 28 \text { females) }\end{array}$ & $\begin{array}{c}61.29 \% \\
\text { (confirmed or } \\
\text { suspected) }\end{array}$ & $\begin{array}{l}\text { Zinc deficiency is one cause } \\
\text { of oral xerostomia }\end{array}$ \\
\hline Iran /Tabriz & 2014(14) & OLP & $\begin{array}{l}44 \text { patients and } 44 \\
\text { healthy controls } \\
(35 \text { males and } 53 \\
\text { females in total) }\end{array}$ & not mentioned & $\begin{array}{l}\text { Serum zinc levels were sig- } \\
\text { nificantly reduced in erosive } \\
\text { OLP compared to non- erosi- } \\
\text { ve OLP. }\end{array}$ \\
\hline
\end{tabular}

RAS, recurrent aphthous stomatitis; OLP, Oral lichen planus; BMS, burning mouth syndrome; AG, atrophic glossitis.

For all participants, blood samples were taken after 12 hours of overnight fasting, medical histories were recorded in detail, and a thorough clinical oral examination was performed by the same professional dentist. The study was approved by the hospital ethics committee and informed consent was obtained from each participant. Serum zinc levels were measured using a Colorimetric Method Zinc Assay Kit (BSBE, Beijing, China). The accepted normal serum zinc level is $10.7-17.70 \mu \mathrm{mol} / \mathrm{L}$. Zinc deficiency was defined as a serum $\mathrm{Zn}$ level below this cutoff.

Statistical analysis was performed using SPSS version 18.0 software (Chicago, Illinois, USA). Serum zinc levels were compared using a t-test to compare between each OMD group and the healthy control group, while one-way ANOVA was used to compare among different groups. In each group, serum zinc levels were compared between male and female using a t-test. In addition, the sex ratio was compared for all groups by Chi-square test. A $p$-value $<0.05$ was accepted as statistically significant.

\section{Results}

- The serum zinc levels

Although the serum zinc levels of some OMD patient groups were still in normative range, the mean serum zinc level of all patients with any OMD was significantly lower than that of the control group ( $p<0.001$, Table 3). 
Table 2. Diagnostic criteria for the oral mucosal diseases involved in the present study.

\begin{tabular}{|c|c|c|c|}
\hline & Inclusion criteria & Exclusion criteria & Appendix \\
\hline $\begin{array}{l}\text { RAS } \\
(1,15,16)\end{array}$ & $\begin{array}{l}\text { The clinical manifestation is } \\
\text { characterized by recurrent oral } \\
\text { ulceration and the history of } \\
\text { recurrence in at least } 1 \text { year. }\end{array}$ & $\begin{array}{l}\text { Behcet's syndrome, HIV, HSV } \\
\text { infection, Oral cancer and other } \\
\text { relevant systemic diseases. }\end{array}$ & $\begin{array}{l}\text { Major and herpetiform RAS } \\
\text { were not included in this study }\end{array}$ \\
\hline $\begin{array}{l}\text { OLP } \\
(14,17,18)\end{array}$ & $\begin{array}{l}\text { The history, typical oral lesions } \\
\text { and skin or nail involvement } \\
\text { are usually sufficient to make a } \\
\text { clinical diagnosis. }\end{array}$ & $\begin{array}{l}\text { Lichenoid drug reactions, lichenoid } \\
\text { reactions induced by dental } \\
\text { restorative material and other } \\
\text { possible systemic diseases such as } \\
\text { GVHD }\end{array}$ & $\begin{array}{l}\text { A biopsy is the recommended } \\
\text { procedure to differentiate it from } \\
\text { other confusable diseases }\end{array}$ \\
\hline $\begin{array}{l}\text { BMS } \\
(4,19)\end{array}$ & $\begin{array}{l}\text { A history of constant burning } \\
\text { discomfort in the anterior tongue, } \\
\text { lower lip, or had palate, for more } \\
\text { than } 6 \text { months, with no evidence } \\
\text { of clinical oral mucosal lesions. }\end{array}$ & $\begin{array}{l}\text { Salivary hypofunction, oral } \\
\text { candidiasis, medication adverse } \\
\text { effects, allergic contact stomatitis, } \\
\text { Diabetes Mellitus and other relevant } \\
\text { medical history. }\end{array}$ & \\
\hline AG (20) & $\begin{array}{l}\text { Partial or complete loss of filiform } \\
\text { papillae on the dorsal surface of } \\
\text { the tongue }\end{array}$ & $\begin{array}{l}\text { Patients with any other relevant } \\
\text { oral mucosal diseases and systemic } \\
\text { diseases, such as OLK, OLP,PV, } \\
\text { pemphigoid, oral candidiasis, } \\
\text { Sjogren's syndrome, Diabetes } \\
\text { Mellitus and diseases of the liver, } \\
\text { kidney }\end{array}$ & \\
\hline $\begin{array}{l}\text { Xerostomia } \\
\text { (13) }\end{array}$ & $\begin{array}{l}\text { Patients who complained of dry } \\
\text { mouth and with reduced salivary } \\
\text { flow rates }\end{array}$ & $\begin{array}{l}\text { Patients with conditions affecting the } \\
\text { salivary gland (Sjogren's syndrome } \\
\text { or radiation to the salivary gland), } \\
\text { relevant medication history and } \\
\text { Diabetes Mellitus and other relevant } \\
\text { systemic diseases }\end{array}$ & \\
\hline
\end{tabular}

RAS, recurrent aphthous stomatitis; OLP, Oral lichen planus; BMS, burning mouth syndrome; AG, atrophic glossitis; HIV, human immunodeficiency virus; HSV, herpes simplex virus; GVHD, Graft-versus-host disease; OLK, oral leukoplakia; PV, pemphigus vulgaris.

Table 3. The basic parameters, zinc levels, and zinc deficiency in each group.

\begin{tabular}{|c|c|c|c|c|c|}
\hline Group & $\begin{array}{c}\text { No. of } \\
\text { subjects }\end{array}$ & $\begin{array}{c}\text { Age } \\
(\text { Mean } \pm \text { SD) }\end{array}$ & $\begin{array}{c}\text { Gender distribution } \\
(\text { male/female })\end{array}$ & $\begin{array}{c}\text { Zinc level } \\
\text { (Mean } \pm \text { SD, } \\
\boldsymbol{\mu m o l} / \mathbf{L})\end{array}$ & $\begin{array}{c}\text { The proportion of } \\
\text { zinc deficiency }\end{array}$ \\
\hline RAS & 156 & $51.57 \pm 16.39$ & $60(38.5 \%) / 96(61.5 \%)$ & $12.90 \pm 2.55$ & $21.2 \%(33)$ \\
\hline OLP & 57 & $52.47 \pm 15.13$ & $13(22.8 \%) / 44(77.2 \%)$ & $14.37 \pm 3.64$ & $14.0 \%(8)$ \\
\hline BMS & 55 & $51.60 \pm 11.21$ & $16(29.1 \%) / 39(70.9 \%)$ & $14.08 \pm 3.06$ & $16.4 \%(9)$ \\
\hline Xerostomia & 46 & $55.30 \pm 11.98$ & $16(34.8 \%) / 30(65.2 \%)$ & $13.33 \pm 3.22$ & $15.2 \%(7)$ \\
\hline AG & 54 & $52.61 \pm 11.52$ & $19(35.2 \%) / 35(64.8 \%)$ & $12.97 \pm 3.10$ & $24.07 \%(13)$ \\
\hline OMD & 368 & $52.33 \pm 14.32$ & $124(33.7 \%) / 244(66.3 \%)$ & $13.37 \pm 3.02$ & $19.02 \%(70)$ \\
\hline Control & 115 & $53.10 \pm 15.59$ & $43(37.4 \%) / 72(62.6 \%)$ & $16.47 \pm 2.10$ & $0(0)$ \\
\hline P-value & -- & 0.626 & 0.467 & $<0.001$ & $<0.001$ \\
\hline
\end{tabular}

RAS: Recurrent aphthous stomatitis. BMS: burning mouth síndrome. AG: atrophic glossitis. OMD: Oral mucosal diseases. 
Each individual in OMD group had a lower mean serum zinc level than the control group $(p<0.001)$.

- Zinc deficiency condition

It is worth noting that in the healthy control group, none of the serum zinc levels fell below the minimum normal value. However, the zinc deficiency rate was 19.02\% (70/368) for patients with any OMD (all OMD groups collectively). Specifically, 24.07\% (13/54) of patients with AG were presented with zinc deficiency, followed by $21.2 \%$ (33/156) of patients with RAS, $16.4 \%(9 / 55)$ of patients with BMS, $15.2 \%$ (7/46) of patients with xerostomia, and 14.0\% (5/57) of patients with OLP. Statistically significant differences were present between all OMD groups and the healthy control group ( $p<0.001$, Table 3$)$.

- Gender differences

Interestingly, the serum zinc levels in males were higher than in females for both the control and OMD groups, with the exception of the AG group. However, these differences were not statistically significant (Table 4). moglobin positivity with AG has been proved (20). In the present study, zinc deficiency was found in nearly a quarter of the AG patients, compared with no deficiency in healthy control. A previous research in Norway revealed that $A G$ was a marker for malnutrition but not related to zinc level (12). However, a more recent and larger scale study in the same Northern Europe country exhibited a relatively high prevalence of zinc deficiency in elderly people and demonstrated the significant association between zinc deficiency and the risk of malnutrition (22). The inconsistent results may be due to the lack of statistical analysis about the prevalence of zinc deficiency of the AG patients in the former study. Similar to our results, the significantly lower serum zinc level or higher prevalence of zinc deficiency was also detected in patients with RAS $(9,10), \operatorname{OLP}(14), \operatorname{BMS}(4,11)$ and xerostomia (13). Further investigation is required to determine if low zinc levels are secondary to or facilitate disease development. However, we would suspect

Table 4. Gender differences in zinc levels in each group.

\begin{tabular}{|c|c|c|c|c|}
\hline \multirow[t]{2}{*}{ Group } & \multicolumn{2}{|c|}{$\begin{array}{c}\text { Zinc level } \\
(\mathrm{Mean} \pm \mathrm{SD}, \mu \mathrm{mol} / \mathrm{L})\end{array}$} & \multirow[t]{2}{*}{ t-value } & \multirow[t]{2}{*}{$P$-value } \\
\hline & Male & Female & & \\
\hline RAS & $12.96 \pm 2.66$ & $12.86 \pm 2.49$ & 0.239 & 0.812 \\
\hline OLP & $15.80 \pm 3.66$ & $13.94 \pm 3.56$ & 1.613 & 0.123 \\
\hline BMS & $14.26 \pm 3.57$ & $14.00 \pm 2.88$ & 0.287 & 0.776 \\
\hline Xerostomia & $14.05 \pm 2.96$ & $12.95 \pm 3.34$ & 1.109 & 0.273 \\
\hline $\mathrm{AG}$ & $12.47 \pm 4.10$ & $13.26 \pm 2.45$ & 0.770 & 0.449 \\
\hline Control & $16.87 \pm 1.60$ & $16.22 \pm 2.33$ & 1.765 & 0.080 \\
\hline
\end{tabular}

RAS: Recurrent aphthous stomatitis. BMS: burning mouth síndrome. AG: atrophic glositis.

\section{Discussion}

Zinc serves as a cofactor of at least 3000 human proteins, and it participants in various molecular mechanisms, which means that zinc deficiency may be more widely and significantly involved in the pathogenesis of human diseases than generally accepted $(6,7,21)$. Zinc deficiency results in multiple abnormalities, which have a positive correlation with occurrence of the oral mucosal diseases discussed in this paper (Fig. 1). In this study, serum zinc levels in OMD patients were significantly lower than or were at the lower end of the normal range, which is in stark contrast to healthy patients that show no signs of zinc deficiency and have zinc levels that are in higher end of the normal zinc range. This simple observation suggests that serum zinc levels maybe influence the pathogenesis of oral mucosal diseases. It is widely believed that atrophic glossitis (AG) may be a marker of nutritional deficiency and the significant association of deficiency of iron, vitamin B12 and he- that low levels of serum zinc are a predisposing factor that may render the individual more susceptible to oral mucosal dysfunction, precipitating the occurrence of OMDs.

The observation that people without OMDs have higher/ normal zinc levels, suggests that zinc homeostasis may play a role in OMD prevention and that exogenous zinc could be potentially used as a treatment or preventative measure for OMDs. Despite our findings that zinc deficiency is common in patients with OMD, additional research is needed to determine if modulation of zinc levels would be therapeutically advantageous. We speculate that zinc supplementation could be beneficial for the treatment of oral mucosal diseases. However, this viewpoint is controversial, as many patients exhibit a poor response to exogenous zinc and there may be a high incidence of undesirable side effects with systemic zinc administration. For example, Wray et al. (8) suggested that a routine of zinc supplementation is not 
advisable/beneficial for patients with RAS. But a more recent article suggested that zinc supplementation may have some positive effects (9). A study in Korea showed that zinc supplementation can be effective against BMS (4), but this view was challenged in a later publication (5). At present, the debate as to the value of zinc supplementation in patients with OMDs continues. Zinc supplementation must be carefully considered, since the optimal level of zinc in the human body is still unknown, and the potential toxic effects of zinc must be considered (21).

We demonstrated that the serum zinc level is likely lower in women than in men. Similar results have been obtained in a large-scale study performed across three European countries (23). Coincidentally, the OMD diseases discussed here are more prevalent in women than man. For example, several studies have denoted that BMS is highly associated with the female gender (24, $25)$. In addition, OLP is twice as common in women as in men (26). Thus, we speculate that the lower level of serum zinc may be one factor that helps explain the increased prevalence of OMD in women.

Our study reveals significant differences in zinc levels between patients with OMD and healthy individuals. Therefore, we postulate that zinc deficiency and lower serum zinc levels are involved in the pathogenesis of oral mucosal diseases and specifically that a decline in a person's serum zinc level may be predisposing factor for the development of an OMD. However, additional study is necessary to determine the efficiency and safe dosing for zinc supplementation in humans, especially considering the overt controversy surrounding this approach. With convenient accessibility and easy traceability, serum zinc levels might also serve a predictive or diagnostic factor for the occurrence of OMDs. Additional research should help to determine the ideal administration strategy and demonstrate the potential effectiveness of zinc supplementation.

\section{References}

1. Stoopler ET, Sollecito TP. Oral mucosal diseases: evaluation and management. Med Clin North Am. 2014;98:1323-52.

2. Scully C. Clinical practice. Aphthous ulceration. N Engl J Med. 2006;355:165-72.

3. Roopashree MR, Gondhalekar RV, Shashikanth MC, George J, Thippeswamy SH, Shukla A. Pathogenesis of oral lichen planus-a review. J Oral Pathol Med. 2010;39:729-34.

4. Cho GS, Han MW, Lee B, Roh JL, Choi SH, Cho KJ, et al. Zinc deficiency may be a cause of burning mouth syndrome as zinc replacement therapy has therapeutic effects. J Oral Pathol Med. 2010;39:722-7.

5. Bhoopathi V, Mascarenhas AK. Zinc-replacement therapy may not reduce oral pain in patients with zinc-deficient burning mouth syndrome (BMS). J Evid Based Dent Pract. 2011;11:189-90.

6. Prasad AS. Discovery of human zinc deficiency: its impact on human health and disease. Adv Nutr. 2013;4:176-90.

7. Maret W. Zinc and human disease. Met Ions Life Sci. 2013;13:389414.
8. Wray D. A double-blind trial of systemic zinc sulfate in recurrent aphthous stomatitis. Oral Surg Oral Med Oral Pathol. 1982;53:46972 .

9. Orbak R, Cicek Y, Tezel A, Dogru Y. Effects of zinc treatment in patients with recurrent aphthous stomatitis. Dent Mater J. 2003;22:21-9.

10. Ozler GS. Zinc deficiency in patients with recurrent aphthous stomatitis: a pilot study. J Laryngol Otol. 2014;128:531-3.

11. Maragou P, Ivanyi L. Serum zinc levels in patients with burning mouth syndrome. Oral Surg Oral Med Oral Pathol. 1991;71:447-50.

12. Bøhmer T, Mowé M. The association between atrophic glossitis and protein-calorie malnutrition in old age. Age Ageing. 2000;29:4750 .

13. Tanaka M. Secretory function of the salivary gland in patients with taste disorders or xerostomia: correlation with zinc deficiency. ActaOtolaryngol Suppl. 2002;546:134-41.

14. Gholizadeh N, Mehdipour M, Najafi Sh, Bahramian A, Garjani $\mathrm{Sh}$, Khoeini Poorfar H. Evaluation of the serum zinc level in erosive and non-erosive oral lichen planus. J Dent (Shiraz). 2014;15:52-6.

15. Preeti L, Magesh K, Rajkumar K, Karthik R. Recurrent aphthous stomatitis. J Oral Maxillofac Pathol. 2011;15:252-6.

16. Jurge S, Kuffer R, Scully C, Porter SR. Mucosal disease series. Number VI. Recurrent aphthous stomatitis. Oral Dis. 2006;12:1-21.

17. Gupta S, Jawanda MK. Oral Lichen Planus: An Update on Etiology, Pathogenesis, Clinical Presentation, Diagnosis and Management. Indian J Dermatol. 2015;60:222-9.

18. Lavanya N, Jayanthi P, Rao UK, Ranganathan K. Oral lichen planus: An update on pathogenesis and treatment. J Oral Maxillofac Pathol. 2011;15:127-32.

19. Pekiner FN, Gümrü B, Demirel GY, Ozbayrak S. Burning mouth syndrome and saliva: detection of salivary trace elements and cytokines. J Oral Pathol Med. 2009;38:269-75.

20. Sun A, Lin HP, Wang YP, Chiang CP. Significant association of deficiency of hemoglobin, iron and vitamin B12, high homocysteine level, and gastric parietal cell antibody positivity with atrophic glossitis. J Oral Pathol Med. 2012;41:500-4.

21. Skrovanek S, DiGuilio K, Bailey R, Huntington W, Urbas R, Mayilvaganan B, et al. Zinc and gastrointestinal disease. World $\mathrm{J}$ Gastrointest Pathophysiol. 2014;5:496-513.

22. Kvamme JM, Grønli O, Jacobsen BK, Florholmen J. Risk of malnutrition and zinc deficiency in community-living elderly men and women: the Tromsø Study. Public Health Nutr. 2015;18:1907-13.

23. Arnaud J, de Lorgeril M, Akbaraly T, Salen P, Arnout J, Cappuccio FP, et al. Gender differences in copper, zinc and selenium status in diabetic-free metabolic syndrome European population - the IMMIDIET study. Nutr Metab Cardiovasc Dis. 2012;22:517-24.

24. Kohorst JJ, Bruce AJ, Torgerson RR, Schenck LA, Davis MD. A population-based study of the incidence of burning mouth syndrome. Mayo Clin Proc. 2014;89:1545-52.

25. Gurvits GE, Tan A. Burning mouth syndrome. World J Gastroenterol. 2013;19:665-72.

26. Scully C, Carrozzo M. Oral mucosal disease: Lichen planus. Br J Oral Maxillofac Surg. 2008;46:15-21.

\section{Acknowledgement}

This study was supported by Shanxi province Health and family planning commission, Science and Technology Key Project (2014018) and Shanxi Scholarship Council of China. The authors would like to thank the Duoease Scientific Service Center for excellent language editing service.

\section{Conflict of interest}

The authors have declared that no conflict of interest exist. 